\title{
COMPARISION OF BIOCHEMICAL CHARACTERISTICS ON INDUCED RESISTANCE AGAINST LEAF BLIGHT DISEASE IN RICE
}

\author{
Toan Le Thanh ${ }^{1,2^{*}}$ Kanjana Thamanu ${ }^{3}$, Rungthip Sangpueak ${ }^{2}$, Miyuki Kusajima ${ }^{4}$, Hideo Nakashita ${ }^{4}$, Sopone \\ Wongkaew $^{2}$, Piyaporn Phansak ${ }^{5}$, Narendra Kumar Papathoti ${ }^{6}$ and Natthiya Buensanteai ${ }^{2}$ \\ ${ }^{1}$ Department of Crop Protection, College of Agriculture, Can Tho University, Can Tho City, 900000, Viet Nam \\ ${ }^{2}$ School of Crop Production Technology, Institute of Agricultural Technology, Suranaree University of Technology, \\ Nakhon Ratchasima, 30000, Thailand \\ ${ }^{3}$ Synchrotron Light Research Institute, Nakhon Ratchasima, 30000, Thailand \\ ${ }^{4}$ Faculty of Bioscience, Fukui Prefectural University, 4-1-1 Kenjojima, Matsuoka, Eiheiji-town, Fukui 910-1195, \\ Japan \\ ${ }^{5}$ Division of Biology, Faculty of Science, Nakhon Phanom University, Muang, Nakhon Phanom, Thailand \\ ${ }^{6}$ R\&D Division, Sri Yuva Biotech Pvt Ltd, Hyderabad, Telangana, India
}

https://doi.org/10.35410/IJAEB.2020.5540

\begin{abstract}
The aim of this study was to compare biochemical traits of two rice leaf positions in induced resistance by 1,2-Benzisothiazol-3 (2H)-one 1,1-dioxide (BIT) at a concentration of $2 \mathrm{mM}$ against leaf blight in rice plants. The results showed that BIT-induced rice leaves had many intense peaks which represented defensive carbohydrates, proteins and lipids. At leaves above the inoculated leaf, exogenous BIT treatment had higher peaks of lipids and proteins, such as 2920, 2851, $1736 \mathrm{~cm}-1$, and the structural change of amide I from alpha helix type at the peak of $1655 \mathrm{~cm}-1$ to $\beta$-sheet type at $1636 \mathrm{~cm}-1$. At rice leaves below the inoculated leaf, its Fourier transform infrared peak assignments of the BIT-induced treatment had significantly spectral peaks at some vibrational peaks of lipids and carbohydrates, such as 2920, 2851, 1319, 1103 and $1040 \mathrm{~cm}-1$. In this study, the elicitor of BIT reduced leaf blight severity by approximately $34.82 \%$.
\end{abstract}

Keywords: bacterial leaf blight, elicitor, induced resistance, rice.

\section{INTRODUCTION}

Rice (Oryza sativa L.) is the major food at the world, providing food safety and livelihoods for billions of people [1] [2]. Rice plays an important role on nutrition and health implication [3]. Rice leaf blight (LB) disease caused by Xanthomonas oryzae pv. oryzae (Xoo) was the most frequently disease at fields in Asia and West Africa [4] [5]. In India, Indonesia, Japan and the Philippines, LB damage was reported to a range of 20-30\% and can reach $75 \%$, depending on locations, rice varieties and environmental conditions [6] [7] [8]. In Africa countries, yield losses caused by Xoo was estimated approximately 30-50\% [9]. The severity of LB losses required the development of eco-friendly and cost-effective strategies for managing. Management of LB is mainly focused on methods of using agro-chemicals, resistant varieties and systemic acquired resistance (SAR) to reduce the initial inoculum and enhance plant health [10] [11]. The SAR, 
based on the increased expression of genes in the host plants, could elicit natural defense mechanisms in rice. The induced plants is able to resist an attack of virulent pathogens by enhancing an array of rapidly expressed defenses upon infection [12]. Induction of disease resistance could be resulted from biotic and abiotic elicitors [13] [14] [15]. In Arabidopsis, foliar sprays of $2 \mathrm{mM}$ 1,2-Benzisothiazol-3 (2H)-one 1,1-dioxide (BIT), could induce an accumulation of salicylic acid (SA) by stimulating the SAR pathway. Levels of free and total SA in the BITtreated Arabidopsis were approximately 7- and 5-fold greater, respectively, at 5 days after treatment [16]. The treatments of 10 and $20 \mathrm{mM}$ salicylic acid, 0.5 and $2 \mathrm{mM}$ jasmonic acid had played a role in reducing bacterial disease caused by Acidovorax avenae in creeping bentgrass (Agrostis stolonifera) [17]. Saccharin could induce SAR responses of soybean (Glycine max) against the infection of rust fungus Phakopsora pachyrhizi [18]. Similarly, saccharin at a spraying concentration of $0.24 \mathrm{mg} \mathrm{mL}^{-1}$ could protect bean plants (Phaseolus vulgaris) against rust and angular leaf spot [19]. An elicitor of acibenzolar-S-methyl highly controlled tobacco blue mould [20], could reduce basil downy mildew at approximately 47-94\% in disease severity [21].

Protection of rice plants from a bacteria's initial penetration is achieved via passive defenses, such as physical and/or chemical barriers such as plant cuticle, cell walls, phenolic compounds, quinones, tannins. When the bacterial pathogens can pass these host passive barriers, the rice plants continue to generate secondary active defenses, including cell wall appositions, callose deposits, lignification, phytoalexins, hypersensitive response, and pathogenesis-related proteins [4]. These active defenses in induced rice plants happen faster than in non-induced ones.

Fourier transform infrared (FTIR) spectroscopy is a fingerprinting tool to differentiate plant metabolic status. The FTIR technique can be used with several different approaches such as hierarchical cluster analysis, principal component analysis and genetic algorithms to detect spectra and formulate possible explanation based on the metabolic differences among elicitortreated and control treatments [22] [23].

The aim of this study was to compare alterations in cell walls of two rice leaf positions occurred during the process of BIT-induced resistance against leaf blight disease.

\section{MATERIALS AND METHODS}

The experiments were carried out at the laboratory and net house of Institute of Agricultural Technology, Suranaree University of Technology and the IR-laboratory of Synchrotron Light Research Institute, Thailand.

\subsection{Rice variety and resistance elicitor}

Seeds of a susceptible rice variety, KDML105, was supported by Rice Research Center, Thailand. Resistance elicitor of BIT, a metabolite of probenazole, was gifted by Prof. Hideo Nakashita, Fukui Prefectural University, Japan.

\subsection{Bacterial strain and culture condition}

Aggressive strain of Xoo was obtained from Plant Pathology and Biopesticide Laboratory, Suranaree University of Technology, Thailand. The Xoo was cultured into $300 \mathrm{ml}$ of nutrient 
broth at $27 \pm 2^{\circ} \mathrm{C}$ for $72 \mathrm{~h}$, with $180 \mathrm{rpm}$ shaking. Finally, the culture medium was re-suspended in sterile distilled water (DW). The density of the bacterial suspension was determined at $10^{8} \mathrm{cfu}$ $\mathrm{mL}^{-1}$ based on optical density of 0.2 at $600 \mathrm{~nm}$ [24].

\subsection{Rice cultivation, induction treatment, disease assessment and sample preparation}

The experiment was conducted with completely randomized design (CRD), five replicates. Rice seeds cv. KDML105 were surface-disinfected by a treatment with $90 \%$ ethanol (v/v) for three min. Next, $50 \mathrm{~g}$ of rice seeds were soaked thoroughly with $100 \mathrm{ml}$ of the solution of BIT at a concentration of $2 \mathrm{mM}$, incubated on wet papers in the dark conditions for one day. Rice seeds treated were planted in $35 \mathrm{~cm}$-plastic pots containing soil, at a net house with a natural light regime $\left(27^{\circ} \mathrm{C}\right.$ and $70-80 \%$ relative humidity). There were two pots per one replication, with two seeds planted per one pot. The rice plants were further treated by foliar sprays with the solution of 2 mM BIT until it ran off, at 15, 30 and 45 days after planting (DAP). On an untreated control, the rice seeds and plants were prepared identically, but DW was used. At each rice pot, tip of six matured leaves of fifty-day-old plants were randomly chosen, cut and dipped into a Xoo suspension at a density of $1 \times 10^{8} \mathrm{cfu} \mathrm{mL}^{-1}$ [25] [26]. Following the artificial inoculation, the plants were put in an inoculation room at the dark conditions with relative humidity of approximately $95 \%$ at $25^{\circ} \mathrm{C}$ for one day. The plants were then kept in the net house with a natural light regime.

LB disease scores were assessed at 7, 14 and 21 days after inoculation (DAI), using a disease scale for assessing rice LB under net house conditions [27]. Disease severity (DS) was calculated as DS $(\%)=$ [Sum of all numerical ratings / (Total number of leaves graded $\mathrm{x}$ Maximum scale)] $\mathrm{x} 100 \%$. Reduction of DS (RDS) for BIT-treated treatment was calculated using a formula as follows: $\operatorname{RDS}(\%)=[(\mathrm{DS}$ of control $-\mathrm{DS}$ of BIT-treatment $) / \mathrm{DS}$ of control $] \times 100 \%$.

Above or below leaf (Figure 1) were sampled at $7 \mathrm{DAI}$, put into an oven at $60^{\circ} \mathrm{C}$ for approximately 3 days, then ground into fine powder by pestles and mortars. Equal weights of powder samples were taken and analyzed by FTIR spectroscopy. 


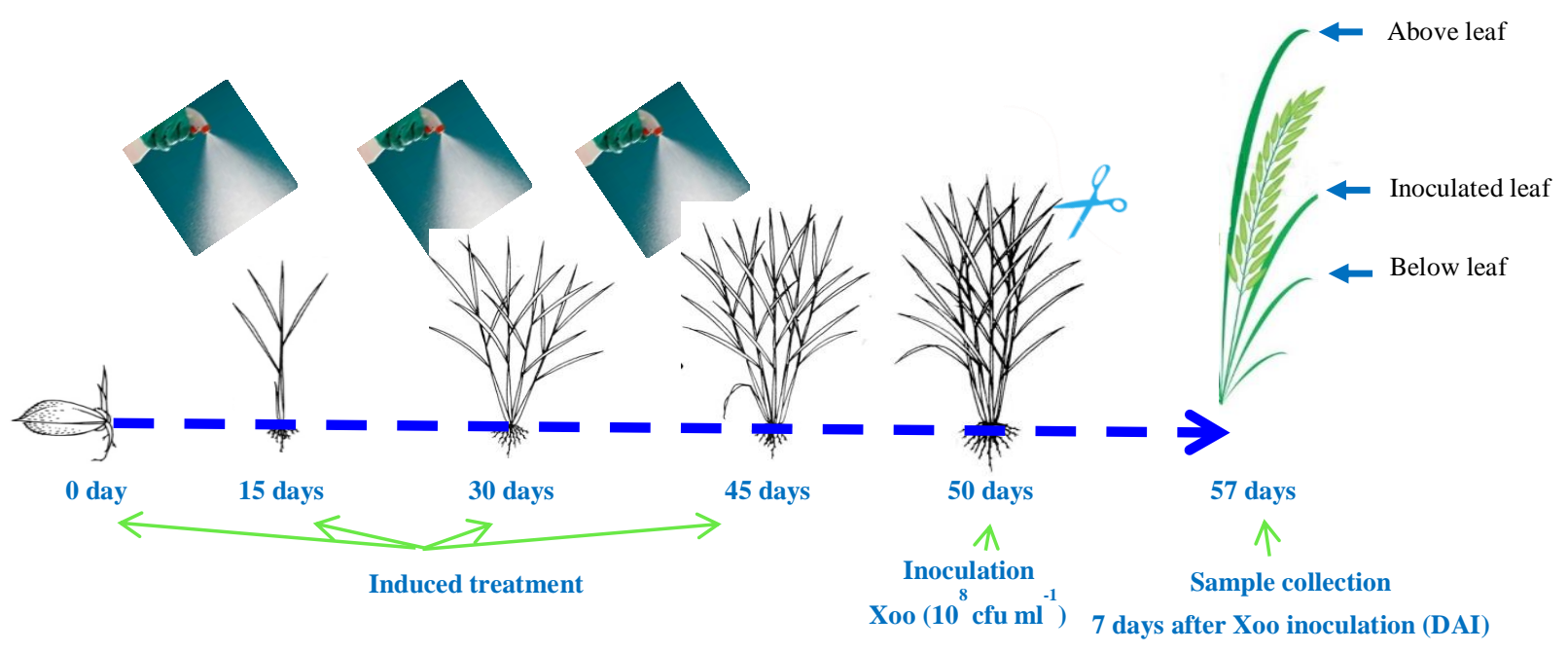

Figure 1: The experimental procedure. Seed soak and foliar sprays with BIT at a concentration of $2 \mathrm{mM}$ on rice $\mathrm{cv}$. KDML105 grown under nethouse conditions at $0,15,30$ and 45 days after planting (DAP). On the untreated control, the rice seeds and plants were handed identically, but distilled water was used instead of BIT. Rice plants were inoculated with Xanthomonas oryzae pv. oryzae (Xoo) at 50 DAP. Two positions of leaves including above leaf and below leaf were collected at 7 days after Xoo-inoculation.

\subsection{Analysis of FTIR spectra}

The spectra were measured by using FTIR spectroscope (Bruker Optics Ltd., Ettlingen, Germany). FTIR spectroscopy in the mid infrared (IR) region of $4000-900 \mathrm{~cm}^{-1}$ at a spectral resolution of $4 \mathrm{~cm}^{-1}$, with 18 spectra per one sample, at Synchrotron Light Research Institute, Thailand [28] [29].

The analytical procedure consisted in calculating the differences in the IR spectra by using OPUS 6.5 software (Bruker optic, German). The individual spectrum from each group was converted to the second derivative, employing nine smoothing points by Savitzky-Golay method and vector normalized by the Extended Multiplicative Signal Correction, to normalize effect of different thickness of the rice leaf powder samples. Unsupervised Hierarchical Cluster Analysis was carried out on IR data using Ward's algorithm to characterize the various biochemical components of the rice leaf tissues over spectral ranges of $3000-2800 \mathrm{~cm}^{-1}$ and $1800-900 \mathrm{~cm}^{-1}$. Peak positions were determined using second derivation [28] [30].

\subsection{Statistical analysis}

Treatment means were separated by Duncan's Multiple Range Test using SPSS software, version 16 (SPSS, Chicago, IL). Significance was determined by the magnitude of F-value at $\mathrm{p}=0.05$. All experiments in the research were repeated three times, with similar results in all replicates.

\section{RESULTS AND DISCUSSION}


The elicitor BIT at a concentration of $2 \mathrm{mM}$ was assessed for its efficacy on SAR by seed soak and foliar sprays at 15, 30 and 45 DAP. The results indicated that the treatment of $2 \mathrm{mM}$ BIT importantly decreased the DS of LB at three observing time points, confirming that the efficacy of BIT on SAR was happened. The DS of BIT-treated rice plants were approximately 19.52, 27.62 and $34.76 \%$ at 7, 14 and 21 DAI, respectively, significantly lower than those of the control one which were $27.14,37.62$ and $53.33 \%$. Reduction of DS in the treatment of $2 \mathrm{mM}$ BIT was approximately $34.82 \%$ at 21 DAI (Table 1 ).

Table 1: Efficacy of BIT at a concentration of $2 \mathrm{mM}$ on severity and reduction of BLB disease in rice cv. KDML 105 caused by Xanthomonas oryzae pv. oryzae under net house conditions

\begin{tabular}{|c|c|c|c|c|c|c|}
\hline \multirow[t]{2}{*}{ Treatment } & \multicolumn{3}{|c|}{ Disease severity $^{1 /}(\%)$} & \multicolumn{3}{|c|}{$\begin{array}{c}\text { Reduction of disease } \\
\text { severity compared with } \\
\text { control }(\%)\end{array}$} \\
\hline & $7 \mathrm{DAI}^{2 /}$ & $14 \mathrm{DAI}^{2 /}$ & $21 \mathrm{DAI}^{2 /}$ & $7 \underset{2 /}{7 \mathrm{DAI}}$ & $14 \underset{2 /}{\mathrm{DAI}}$ & $21 \underset{2 /}{\mathrm{DAI}}$ \\
\hline BIT-treated & $\begin{array}{l}19.52 \pm 3.9 \\
1 b\end{array}$ & $\begin{array}{l}27.62 \pm 2.1 \\
3 b\end{array}$ & $\begin{array}{l}34.76 \pm 2.1 \\
2 b\end{array}$ & 28.08 & 26.58 & 34.82 \\
\hline Non-treated control & $\begin{array}{l}27.14 \pm 2.7 \\
1 \mathrm{a}\end{array}$ & $\begin{array}{l}37.62 \pm 6.1 \\
6 \mathrm{a}\end{array}$ & $\begin{array}{l}53.33 \pm 5.7 \\
3 a\end{array}$ & & & \\
\hline Significance & $* *$ & $* *$ & $* *$ & & & \\
\hline $\begin{array}{l}\text { Coefficient of } \\
\text { Variation }(\%)\end{array}$ & 5.12 & 6.83 & 10.60 & & & \\
\hline
\end{tabular}

Rice plants were treated by seed soak and foliar spays at 15, 30 and 45 days after planting (DAP), with $2 \mathrm{mM}$ BIT or distilled water as a control, and then inoculated with Xanthomonas oryzae pv. oryzae suspension at a density of $1 \times 10^{8} \mathrm{cfu} \mathrm{m}^{-1}$ at $50 \mathrm{DAS}$. The data were means \pm S.E. with five replications, two rice plants per one replication, three leaves per one rice plant. BIT-treated: susceptible rice cultivar cv. KDML105 treated with BIT at a concentration of $2 \mathrm{mM}$; Non-treated control: susceptible rice cultivar cv. KDML105 treated with distilled water.

${ }^{1 /}$ Mean \pm SE (standard error) followed by the same letter do not differ significantly according to Duncan's multiple range test at $\mathrm{P}=0.05$

${ }^{2 /}$ DAI: Days after inoculation

In order to compare the effect of elicitor BIT on the systemic defense responses of two rice leaf positions, the biochemical alterations of rice leaves were characterized by FTIR spectroscopy analysis. Original and second derivative average spectra of rice leaves of BIT-induced treatment and diseased control in the range of 3000-2800 and 1800-900 $\mathrm{cm}^{-1}$, were shown in Fig. 2 and 3. 
Biochemical roles of specific spectral peaks were described in several papers of bio-researches, but the study of FTIR on induced resistance is not much (Table 2). The spectral range of 3000$2800 \mathrm{~cm}^{-1}$ was shown in Fig. 3a and 3c. The broad bands at the peaks of 2920 and $2851 \mathrm{~cm}^{-1}$, both belong to $\mathrm{C}-\mathrm{H}$ asymmetric and symmetric vibration, were more intense in treatment of BIT. The differences on spectral ranges of $1800-900 \mathrm{~cm}^{-1}$ of non-treated and BIT-treated leaves are shown in Fig. $3 \mathrm{~b}$ and $3 \mathrm{~d}$. At above rice leaves, the BIT-treated treatment had one importantly higher peak at $1736 \mathrm{~cm}^{-1}$, assigned to stretching vibration of $\mathrm{C}=\mathrm{O}$ ester. Moreover, alpha helix form $\left(1655 \mathrm{~cm}^{-1}\right)$ of amide I in BIT-treated rice leaves appeared more intense than $\beta$-sheet one $\left(1636 \mathrm{~cm}^{-1}\right)$. However, the alpha helix peak greatly remained in the control (Fig. 3b). At below rice leaves, their FTIR peak assignments of the BIT-induced treatment had three importantly higher vibrational peaks, including $1319 \mathrm{~cm}^{-1}$ (assigned to C-C, C-O skeletal of hemicellulose and lignin), $1103 \mathrm{~cm}^{-1}$ (C-O-C glycoside of hemicellulose) and $1040 \mathrm{~cm}^{-1}$ (C-O-C of polysaccharides) (Fig. 3d). One of the most important characteristics of induced resistance is systemic. After the first infection from Xoo, induced rice plants could create signals and defense responses at other parts of plants, both above and below rice leaves. The interesting questions remain to be explored are which leaf position has more biochemical defense responses in and what defense responses at each leaf position. The results showed that above leaves have increased defense responses on lipids and protein, while below leaves have more significant alterations on lipids and carbohydrates.

Table 2: Band assignments of FTIR vibration peak $\left(\mathrm{cm}^{-1}\right)$ of plant rice leaf tissues based on references

\begin{tabular}{|c|c|c|c|}
\hline Peak name & $\begin{array}{l}\text { Spectral } \\
\text { ranges }\end{array}$ & Vibration peak assignments & References \\
\hline $\begin{array}{l}\mathrm{C}-\mathrm{H} \\
\text { stretching } \\
\text { vibration }\end{array}$ & $\begin{array}{l}3000- \\
2800\end{array}$ & $\begin{array}{l}\text { C-H Asymmetric and } \\
\text { Symmetric stretching } \\
\text { vibration of mainly lipid } \\
\text { groups with the little } \\
\text { contribution from protein, }\end{array}$ & [31] [32] [33] \\
\hline $\mathrm{C}=\mathrm{O}$ esters & $\begin{array}{l}1740- \\
1700\end{array}$ & $\begin{array}{l}\text { Stretching vibration of } \mathrm{C}=\mathrm{O} \\
\text { ester of bond lipid, lignin, } \\
\text { pectin or their esters }\end{array}$ & [31] [33] [34] [35] [36] \\
\hline Amide I & $\begin{array}{l}1700- \\
1600\end{array}$ & $\begin{array}{l}\text { Amide I due to } \mathrm{C}=\mathrm{O} \\
\text { stretching of } \alpha \text {-helix protein, } \\
\text { contribution from } \mathrm{C}-\mathrm{N} \\
\text { stretching }(\mathrm{C}=\mathrm{O} \text { stretch } \\
(80 \%), \mathrm{C}-\mathrm{N} \text { stretch }(10 \%), \mathrm{N}- \\
\mathrm{H} \text { bending }(10 \%))\end{array}$ & [33] [34] [37] [38] \\
\hline Amide II & $\begin{array}{l}1600- \\
1500\end{array}$ & $\begin{array}{l}\text { Amide II due to } \mathrm{N}-\mathrm{H} \text { bending } \\
\text { and } \mathrm{C}-\mathrm{N} \text { stretching of protein } \\
(\mathrm{N}-\mathrm{H} \text { bend }(60 \%), \quad \mathrm{C}-\mathrm{N}\end{array}$ & [34] \\
\hline
\end{tabular}




\begin{tabular}{|c|c|c|}
\hline Peak name & $\begin{array}{l}\text { Spectral } \\
\text { ranges }\end{array}$ & Vibration peak assignments \\
\hline & & $\operatorname{stretch}(40 \%))$ \\
\hline $\begin{array}{l}\mathrm{C}=\mathrm{O} \\
\text { aromatic ring }\end{array}$ & 1517 & $\begin{array}{l}\mathrm{C}=\mathrm{C} \quad \text { aromatic } \\
\text { lignin, } \mathrm{C}-\mathrm{H} \text { bend }\end{array}$ \\
\hline C-H bending & $\begin{array}{l}1470- \\
1350\end{array}$ & $\begin{array}{l}\mathrm{C}-\mathrm{H} \text { bending from } \mathrm{CH} 2 \text { and }[34][35] \\
\mathrm{CH} 3 \text { from mainly lipids and } \\
\text { lignin }\end{array}$ \\
\hline $\begin{array}{l}\mathrm{C}-\mathrm{O} \\
\text { stretching } \\
\text { hemicellulose } \\
\text { and lignin }\end{array}$ & $\begin{array}{l}1300- \\
1200\end{array}$ & C-C, C-O skeletal \\
\hline $\begin{array}{l}\text { C-C ring } \\
\text { cellulose }\end{array}$ & 1165 & $\mathrm{C}-\mathrm{C}$ ring from cellulose \\
\hline $\begin{array}{l}\text { C-O-C } \\
\text { glycoside }\end{array}$ & 1103 & $\begin{array}{l}\text { C-O-C glycoside ether mainly [36] } \\
\text { hemicellulose }\end{array}$ \\
\hline $\begin{array}{l}\mathrm{C}-\mathrm{C} \text { bond of } \\
\text { cellulose }\end{array}$ & $\begin{array}{l}1080- \\
1022\end{array}$ & $\begin{array}{l}\text { Stretching vibration of C-OH }[31][34][40][41] \\
\text { of alcohic groups and } \\
\text { carboxylic acid, C-C bond of } \\
\text { the cellulose sugar rings. } \\
\text { Mainly C-O-C of } \\
\text { polysaccharides }\end{array}$ \\
\hline $\begin{array}{l}\mathrm{C}-\mathrm{O} \text { bonds of } \\
\text { sucrose }\end{array}$ & 995-988 & $\begin{array}{l}\text { endocyclic and exocyclic C-O } \\
\text { bonds of cello-triose, - } \\
\text { tetraose, and -pentose }\end{array}$ \\
\hline
\end{tabular}

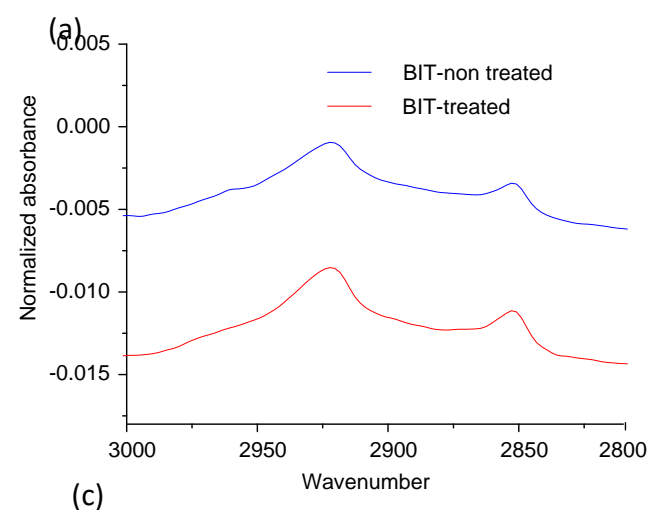

(c)

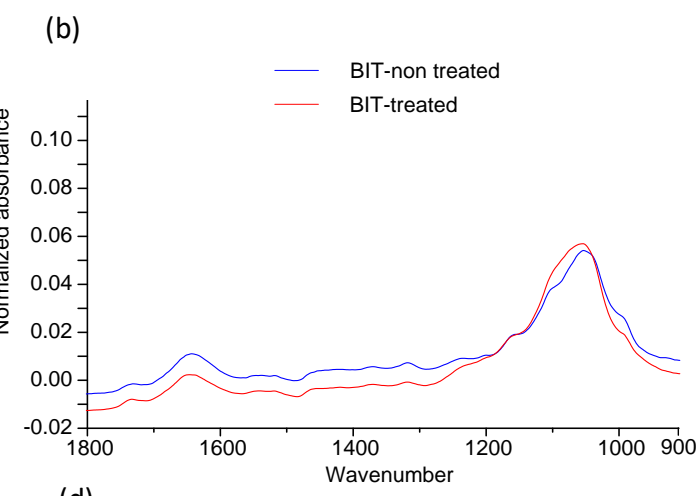

(d) 

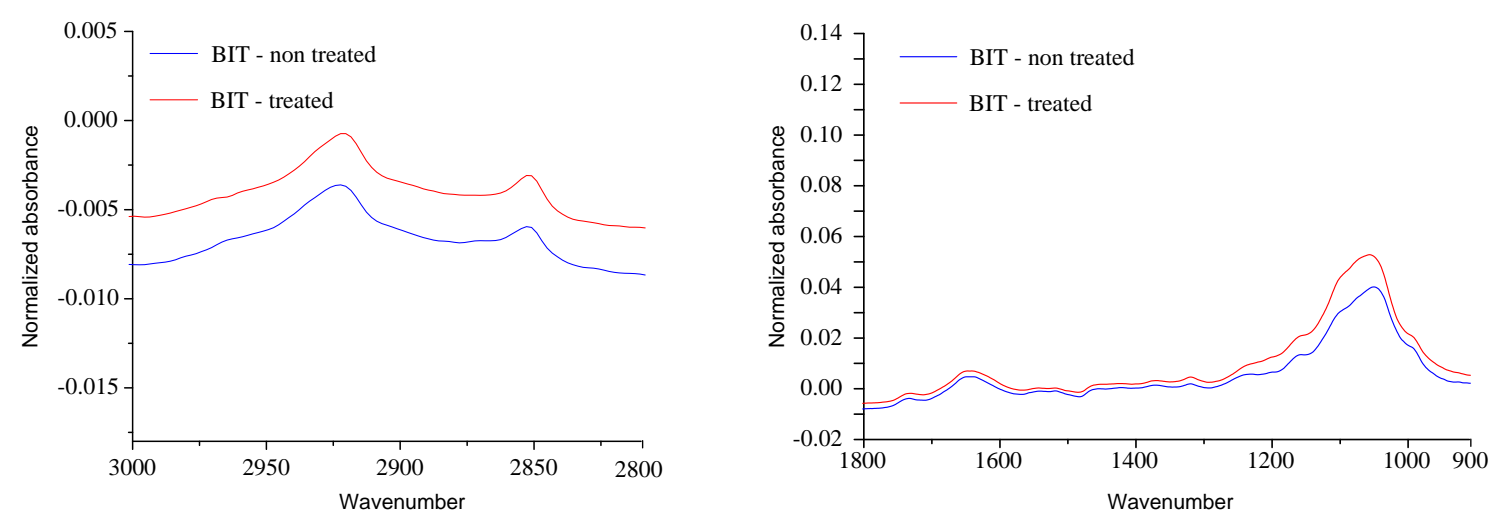

Figure 2: Representative original average FTIR spectra in KDML 105 rice leaves treated with $2 \mathrm{mM}$ BIT and inoculated with Xoo, at 7 DAI, under nethouse conditions. (a), (b) Representative original average FTIR spectra in leaves above the inoculated leaf; (c), (d) Representative original average FTIR spectra in leaves below the inoculated leaf. Twelve spectra per group were preprocessed by taken second derivative spectra after 9 points of smoothing and normalized with EMSC over the range.

(a)
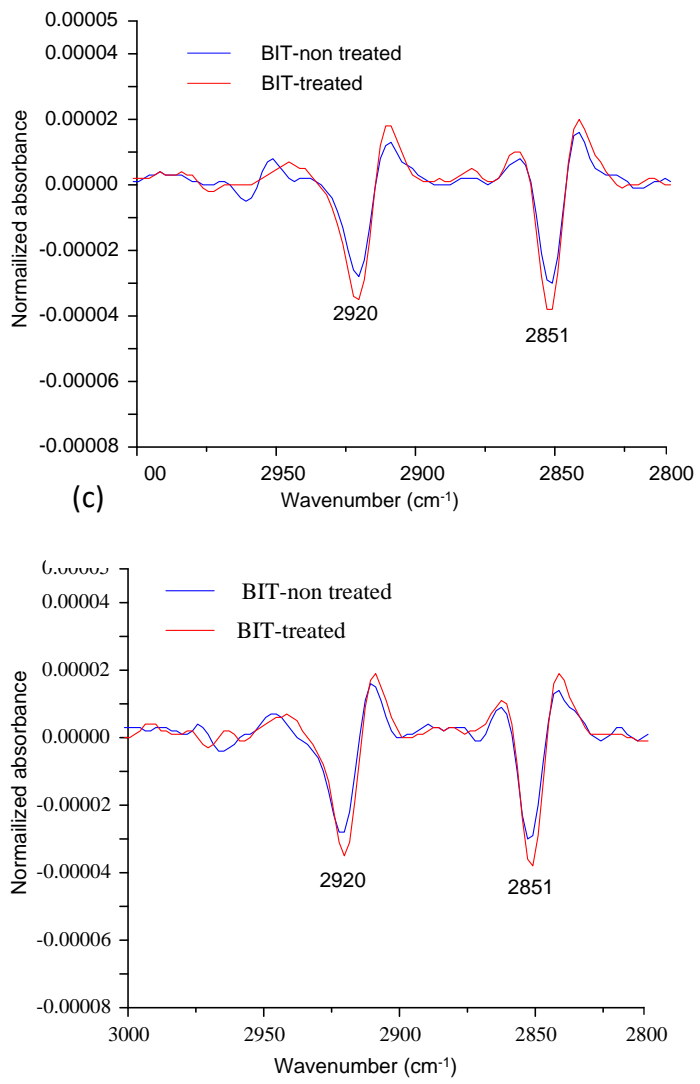

(b)
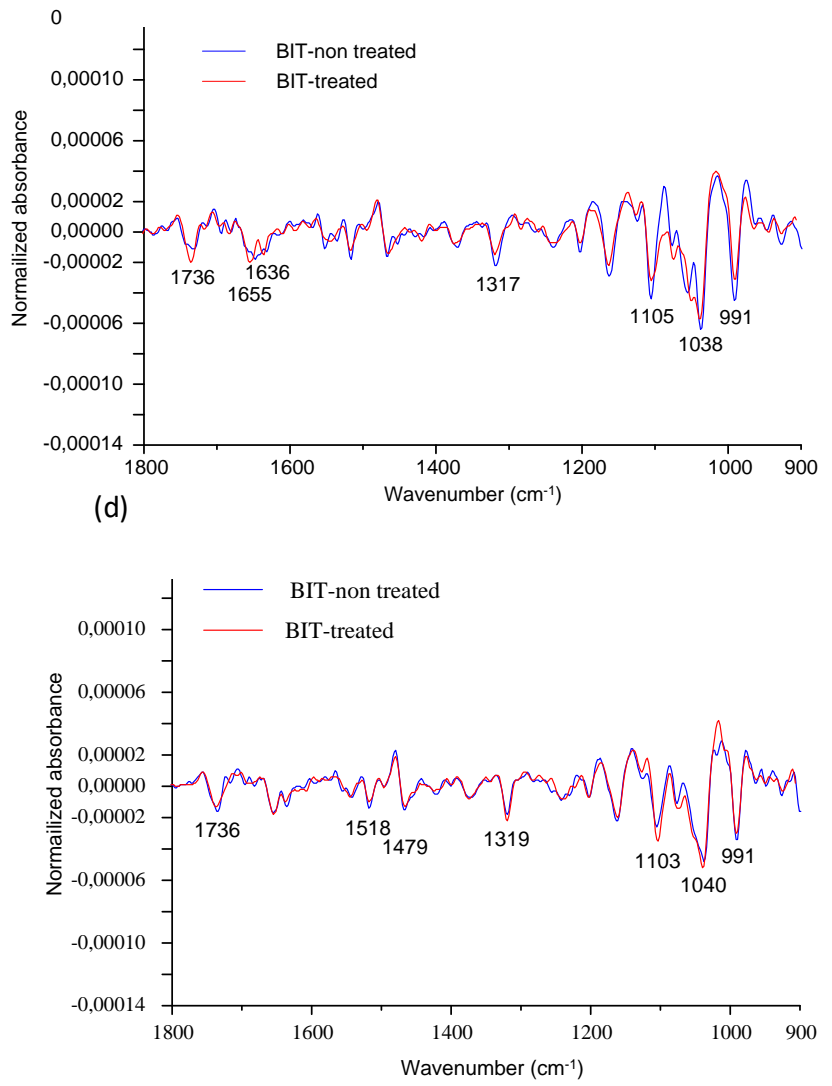
Figure 3: Second derivative average spectra in KDML 105 rice leaves treated with 2 $\mathrm{mM}$ BIT and inoculated with Xoo, at 7 DAI, under nethouse conditions. (a), (b) Second derivative average spectra in leaves above the inoculated leaf; (c), (d) Second derivative average spectra in leaves below the inoculated leaf. Twelve spectra per group were preprocessed by taken second derivative spectra after 9 points of smoothing and normalized with EMSC over the range.

Principal component analysis (PCA) is a common technique for a reduction of sample dimensionality. Two-dimensional PCA analyses in above and below rice leaves were presented on Fig. 4 and 5, respectively. The blue points of the control were separated from the red points representing the BIT-treatment, both in above (Fig. 4a) and below (Fig. 5a) rice leaves

(b)
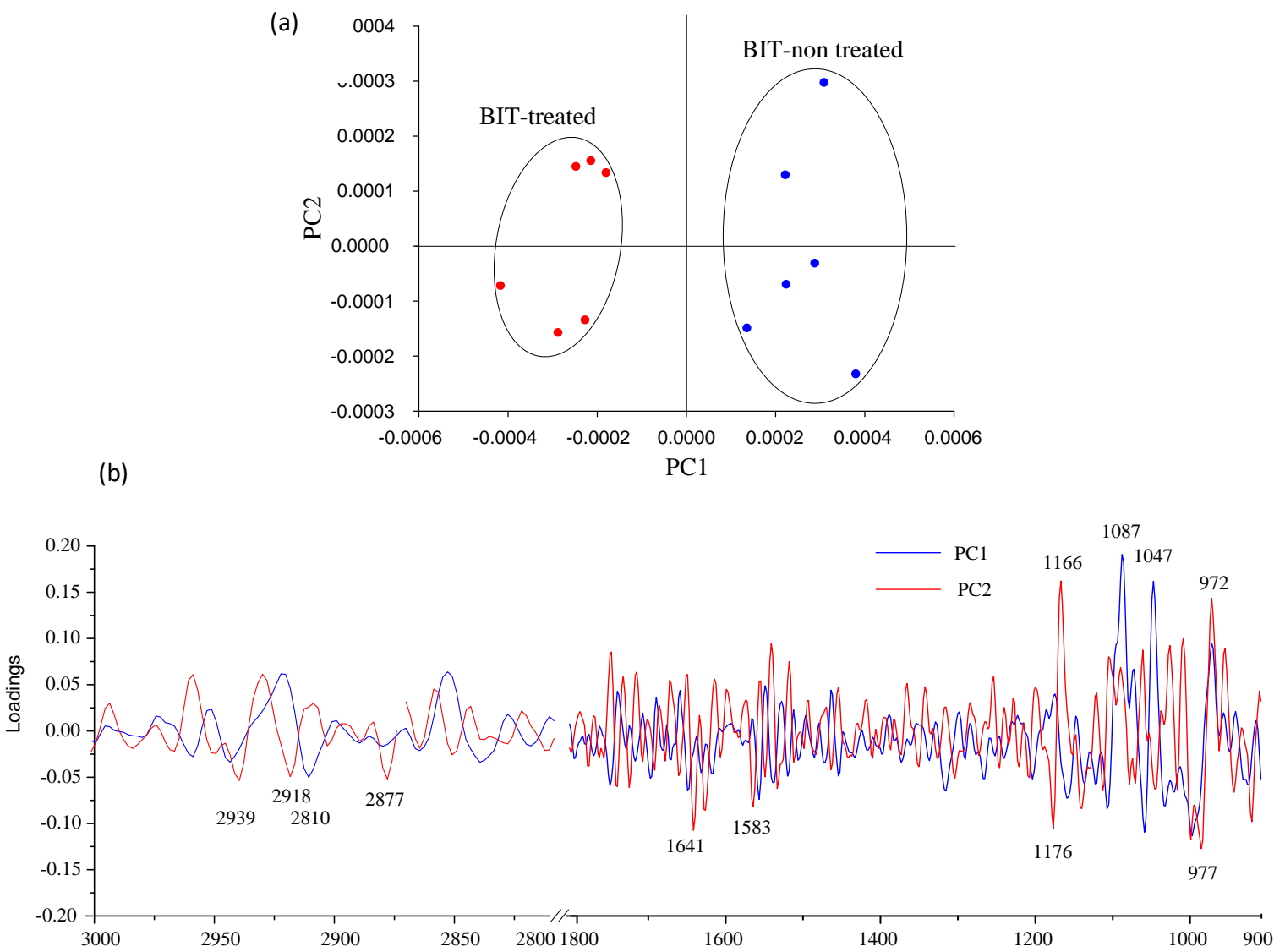

Figure 4: PCA analysis in rice leaves above the inoculated leaf, at 7 DAI, under nethouse conditions. (a) 2D scatter plot of score from a PCA analysis. (b) Loading plots from a PCA analysis in the range of 3000-2800 and $1800-900 \mathrm{~cm}^{-1}$ 


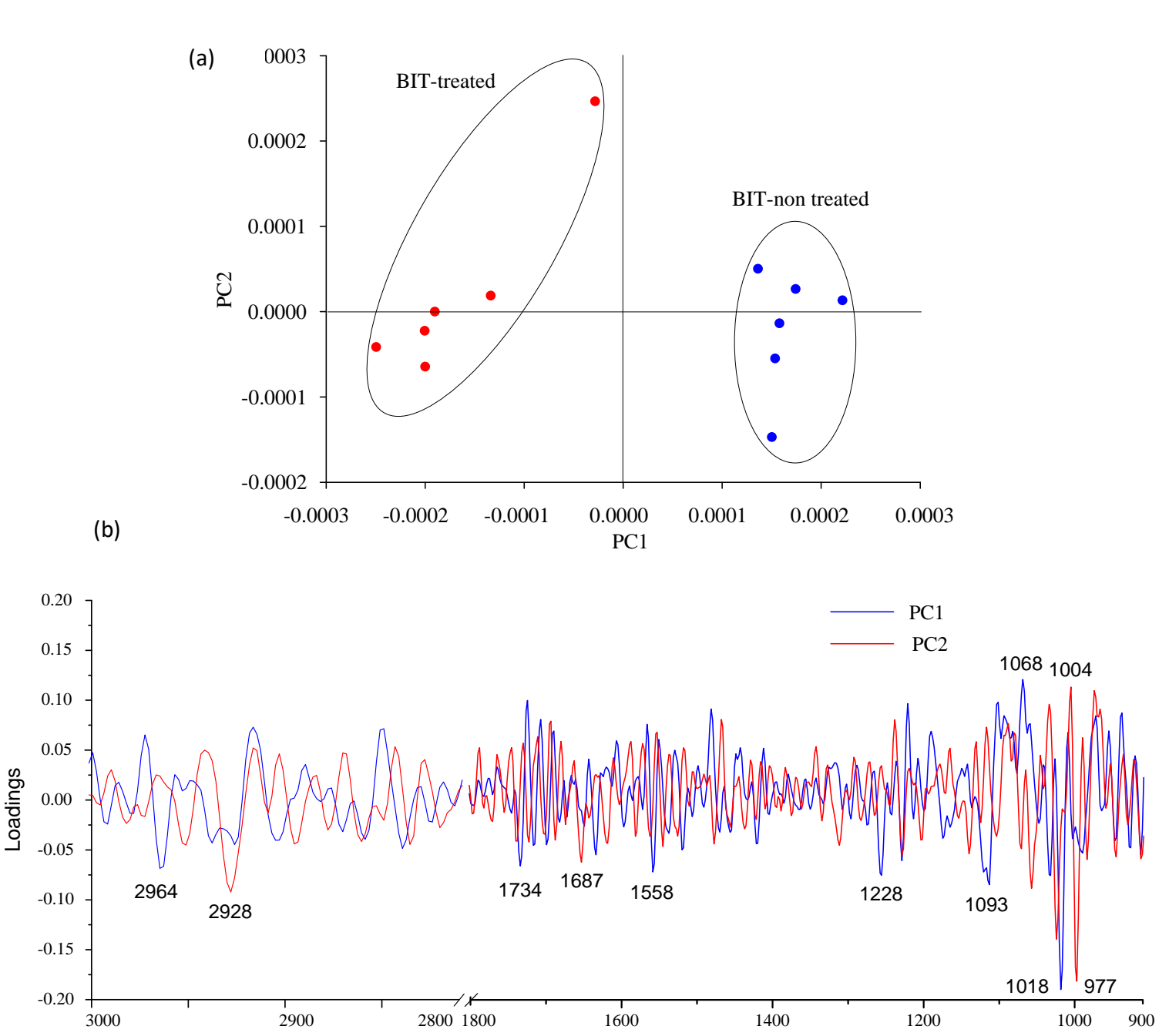

Figure 5: PCA analysis in rice leaves below the inoculated leaf, at 7 DAI, under nethouse conditions. (a) 2D scatter plot of score from a PCA analysis. (b) Loading plots from a PCA analysis in the range of 3000-2800 and $1800-900 \mathrm{~cm}^{-1}$.

A classification procedure by the cluster analysis was carried out to investigate more information about the biochemical differences among the cell wall of rice leaves on induced resistance (Fig. 6). The cluster analysis is a technique to examine inter-point distances between rice samples as well as presents that information in the type of a two-dimensional plot or a dendrogram. The dendrogram of above leaves' spectra displays two main branches which separated approximately 0.6 unit. The spectra within the above branch are the treatment treated by BIT at a concentration of $2 \mathrm{mM}$. The below branch contains only the diseased control (Fig. 6a). Lastly, the dendrogram corresponding to the cell wall spectra from below leaves is displayed in Fig. 6c. At 7 DAI, the above branch is separated by 0.4-0.6 unit from the below one and comprised of all spectra of the BIT-treated and disease control, respectively. 


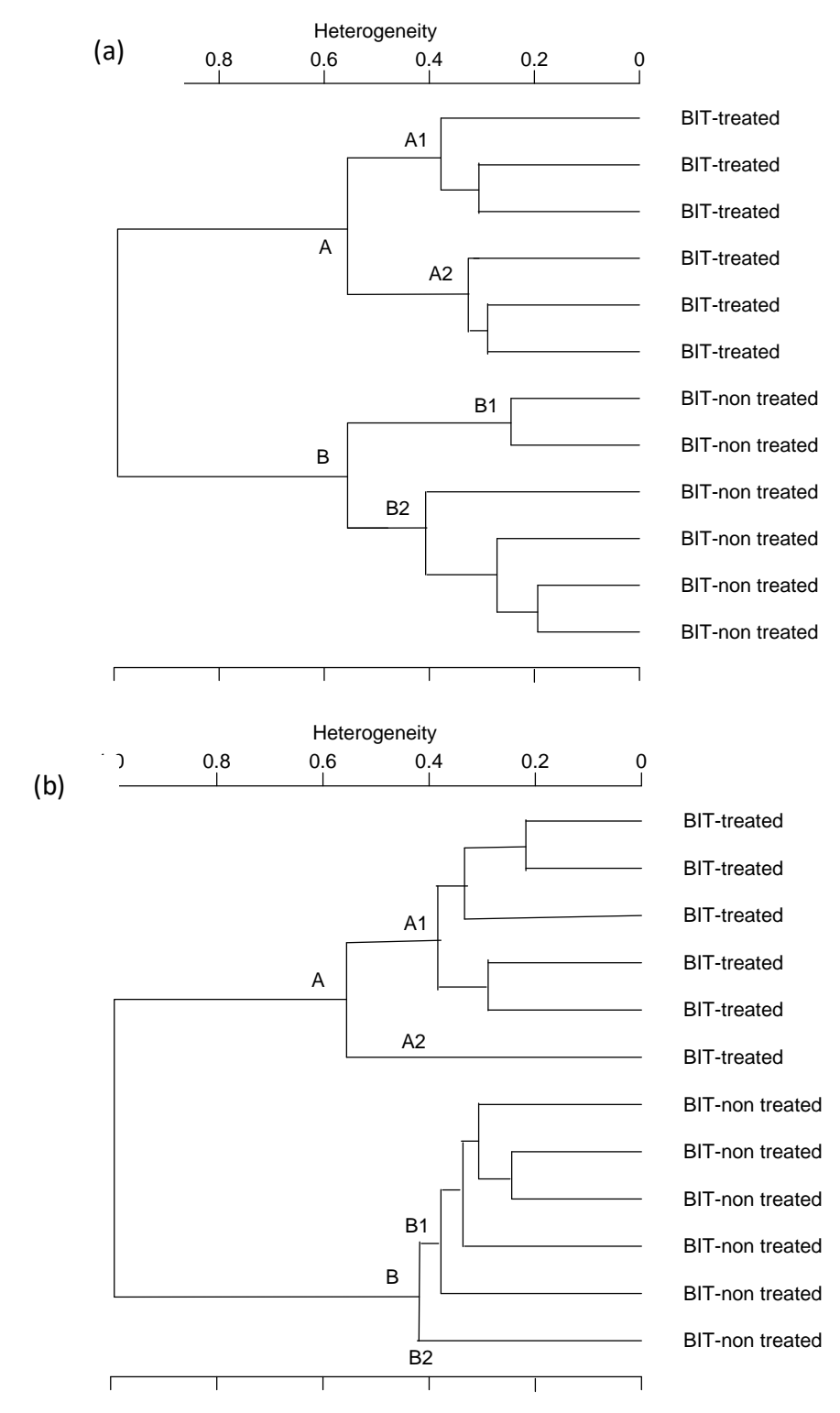

Figure 6: Cluster analysis of FTIR spectra in the range of $3000-2800$ and $1800-900 \mathrm{~cm}^{-1}$ in rice leaves, at 7 DAI, under nethouse conditions. (a): leaves above the inoculated leaf, (b): leaves below the inoculated leaf

In addition, to further find out alterations of lignins and pectins in BIT-treated rice leaves, three ratios of 1233/1517, 1467/1517, and 1735/1517 $\mathrm{cm}^{-1}$ were specified. At above and below leaves, these biochemical ratios of BIT-treated treatment showed that approximately 20-80 percentage of 
pectins and lignins were significantly accumulated (Fig. 7a and 7b).
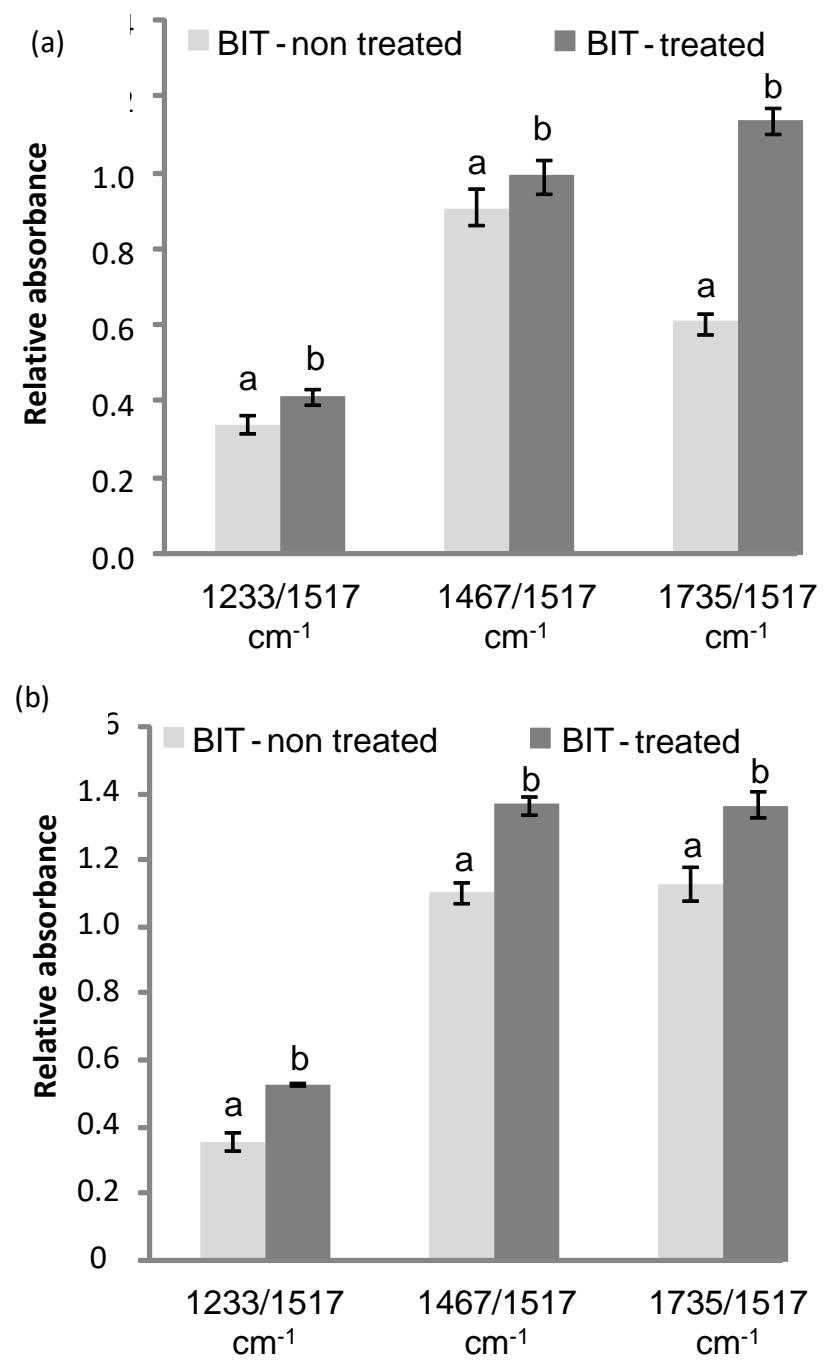

Figure 7: Relative absorbance ratio of some spectral peaks to the intensitive at $1517 \mathrm{~cm}^{-1}$ in KDML 105 rice leaves treated or non treated with BIT $2 \mathrm{mM}$, at 7 DAI, under nethouse conditions. Error bars represent standard deviation from 6 replications. At each ratio assessed, values followed by the same letter are not significantly different according to Duncan's multiple range test at $\mathrm{P}=0.05$. Ratio of $1233 / 1517 \mathrm{~cm}^{-1}$ represents methoxyphenolic substitution in aromatic units of lignin. Ratio of $1467 / 1517 \mathrm{~cm}^{-1}$ is the ratio of syringyl to guaiacyl (S/G) of lignin. Ratio of $1735 / 1517 \mathrm{~cm}^{-1}$ is representative of an alteration in pectin synthesis. (a): leaves above the inoculated leaf, (b): leaves below the inoculated rice leaf 
Many available analysis tools can be used for studying induced resistance at cellular and subcellular levels as plant histopathological methods, transcriptome, proteome, secondary metabolites [43] [44]. Cell wall components can be analyzed by many methods, including immunolocalization, GC-MS and histochemical staining [45] [46]. However, these methods require labor-intensive in case of treating lots of samples [39]. FTIR is advantageous because the strategy to reveal good spectra of each biological sample. FTIR combined with several different statistical approaches could be a valuable method to detect, classify and formulate the contribution of biological components on the metabolic differences among treated and control treatments [22] [32]. However, few studies were carried on using FTIR as a tool to identify changes in cellular components on induced resistance, especially in the rice plant.

Resistance to LB disease in rice leaves largely resulted from the ability of their cells to modify the composition and structure of their cell walls. The below rice leaves showed more biochemical alterations in the cell walls than above ones. Therefore, below leaves should be used for the identification of cell wall changes related to assess the ability of the elicitor on induced resistance against pathogens in rice plants. On qualitative analyses, FTIR absorption band area values of C-C, C-O skeletal of hemicellulose and lignin, C-O-C glycoside of hemicellulose, and $\mathrm{C}-\mathrm{O}-\mathrm{C}$ of polysaccharides could be used as indicators of induced resistance to LB disease in rice plants. Wang et al. [39] investigated the composition of wheat cell wall contributing to stem lodging resistance by FTIR spectroscopy and concluded that it was not possible to use only one peak intensity as a predictor on FTIR spectra between different developmental internodes.

\section{CONCLUSION}

The currently available information on induced resistance in this study suggests that the elicitor of BIT has a great potential application on LB management. FTIR spectroscopy offers a new tool to characterize biochemical alterations on rice plant responses to LB disease. Emphasis has given to the changes of defensive carbohydrates, proteins and lipids in induced rice plants. The above rice leaves have dominant defense responses on lipids and proteins, while activities of resistance lipids and carbohydrates occur highly on the below rice leaves. The precious information of spectral peaks such as $\mathrm{C}-\mathrm{C}, \mathrm{C}-\mathrm{O}$ skeletal of hemicellulose and lignin, C-O-C glycoside of hemicellulose, and $\mathrm{C}-\mathrm{O}-\mathrm{C}$ of polysaccharides is also used as biomarkers to quickly investigate the occurrence of disease resistance in induced rice plants.

\section{ACKNOWLEDGEMENTS}

Authors wish to express our special thanks to the SUT-ASEAN scholarship from Suranaree University of Technology for providing the financial support.

\section{REFERENCES}

[1] S.S. Pastelero, R.L. Ines, "Evaluation of different water application method for promising aerobic rice (Oryza sativa L.) variety (PSBRc9)", International Journal of Agriculture, Environment and Bioresearch, 3(1), 44-59, 2018. 
[2] K. Alexis, N. Fidele, G. Julienne, "Rice growers' financial credit access in Bugarama irrigation scheme in Rwanda", International Journal of Agriculture, Environment and Bioresearch, 3(2), 145-155, 2018.

[3] P.A.N. Thushara, P.I. Godakumbura, M.A.B. Prashantha, "Important, health benefits amd bioactivities of Sri Lankan traditional rice (Oryza sativa L.) varieties: a review". International Journal of Agriculture, Environment and Bioresearch, 4(3), 119-128, 2019.

[4] G.N. Agrios, Plant pathology (5 ${ }^{\text {th }}$ Ed.), Academic Press, San Diego, USA, pp 93-142, 2005.

[5] J.D. Janse, Phytobacteriology: principles and practice. CABI, Wallingford, UK, pp. 360, 2005.

[6] S.H. Ou, Rice diseases. CABI, Wallingford, UK, 1972.

[7] S.H. Ou, Rice diseases, $2^{\text {nd }}$ Ed. Commonwealth Mycological Institute, Kew, UK, 221p, 1985.

[8] T. Le Thanh, K. Thumanu, S. Wongkaew, N. Boonkerd, N. Teaumroong, P. Phansak, N. Buensanteai, "Salicylic acid-induced accumulation of biochemical components associated with resistance against Xanthomonas oryzae pv oryzae in rice", Journal of Plant Interaction, 12, pp. 108-120, 2017.

[9] V. Verdier, , C.V. Cruz, J.E. Leach, "Controlling rice bacterial leaf blight in Africa: Needs and prospects", Journal of Biotechnology, 159, pp. 320-328, 2012.

[10] S.S. Gnanamanickam, Biological control of rice diseases, Springer Science \& Business Media B.V., Berlin/Heidelberg, Germany, 208p, 2009.

[11] B.N. Fitriatin, P. Tamara, O. Mulyani, E.T. Sofyan, A. Yuniarti, T. Turmuktini, "Influence of biofertilizer and humic acid on NPK content and yield of rice (Oryza sativa L.)", International Journal of Agriculture, Environment and Bioresearch, 3(3): 20-27, 2018.

[12] R. Hammerschmidt, "Introduction: definitions and some history", in Induced resistance for plant defence - A sustainable approach to crop protection, D. Walter, A. Newton, G. Lyon (Eds.), Blackwell Publishing Ltd., Oxford (UK), pp. 1-8, 2007.

[13] A. Ibrahim, A.A. Shahid, A. Ahmad, "Evaluation of carrier materials to develop Bacillus subtilis formulation to control root knot nematode infection and promote agroeconomic traits in eggplant", Journal of Animal and Plant Sciences, 27 (4), pp. 1321-1330, 2017.

[14] N. Khan, R. Batool, N. Jamil, "Organic anions production by Bacillus sp. to enhance maize and millet growth", Journal of Animal and Plant Sciences, 27 (6), pp. 2035-2044, 2018.

[15] A.M. Shaheen, E.H. Abd El-Samad, F.A. Rizk, A.G. Behairy, S.M. Adam, "Effect of application methods of plant growth stimulation on growth and yield of snap bean", Journal of Animal and Plant Sciences, 28 (3), pp. 854-864, 2018. 
[16] M. Yasuda, H. Nakashita, S. Hasegawa, M. Nishioka, Y. Arai, M. Uramoto, I. Yamaguchi, $\mathrm{S}$. Yoshida, "N-Cyanomethyl-2-chloroisonicotinamide induces systemic acquired resistance in Arabidopsis without salicylic acid accumulation", Bioscience, Biotechnology and Biochemistry, 67, pp. 322-328, 2003.

[17] S. Liu, , J. Vargas, E. Merewitz, "Jasmonic and salicylic acid effects on bacterial etiolation and decline disease of creeping bentgrass", Crop Protection, 109, pp. 9-16, 2018.

[18] P. Srivastana, S. George, J.J. Marois, D.L. Wright, D.R. Walker, "Saccharin-induced systemic resistance against rust (Phakopsora pachyrhizi) infection in soybean: Effects on growth and development", Crop Protection, 30, pp. 726-732, 2011.

[19] D.Z. Delgado, M.B. de Freitas, M.J. Stadnik, "Effectiveness of saccharin and ulvan as resistance inducers against rust and angular leaf spot in bean plants (Phaseolus vulgaris)", Crop Protection, 47, pp. 67-73, 2013.

[20] J.A. LaMondia, "Efficacy of fungicides and a systemic acquired resistance activator (acibenzolar-S-methyl) against tobacco blue mould”, Crop Protection, 28, pp. 72-76, 2009.

[21] Z. Mersha, S. Zhang, R.N. Raid, "Evaluation of systemic acquired resistance inducers for control of downy mildew on basil", Crop Protection, 40, pp. 83-90, 2012.

[22] A.S. Motta, F.S. Flores, A.A. Souto, A. Brandelli, "Antibacterial activity of a bacteriocinlike substance produced by Bacillus sp. P34 that targets the bacterial cell envelope", Antonie Van Leeuwenhoek, 93 (3), pp. 275-284, 2008.

[23] A. Largo-Gosens, M. Hernández-Altamirano, L. García-Calvo, A. Alonso-Simón, J. Álvarez, J.L. Acebes, "Fourier transform mid infrared spectroscopy applications for monitoring the structural plasticity of plant cell walls", Frontiers in Plant Science, 5 (303), pp. 1-15. 2014.

[24] N. Buensanteai, D. Athinuwat, C. Chatnaparat, G.Y. Yuen, S. Prathuangwong, "Extracellular proteome of plant growth promoting-bacteria, Bacillus amyloliquefaciens KPS46 and its effect on enhanced growth promotion and induced systemic resistance on soybean", Kasetsart Journal - Natural Science, 42, pp. 13-26, 2008.

[25] S. Nisha, K. Revathi, R. Chandrasekaran, S.A. Kirubakaran, S.S. Narayanan, M.S. Stout, S.S. Nathan, "Effect of plant compounds on induced activities of defense-related enzymes and pathogenesis related protein in bacterial leaf blight susceptible rice plant", Physiological and Molecular Plant Pathology, 80, pp. 1-9, 2012.

[26] J. Xu, K. Audenaert, M. Hofte, A. De Vleesschauwer, "Abscisic acid promotes susceptibility to the rice leaf blight pathogen Xanthomonas oryzae pv oryzae by suppressing salicylic acid-mediated defenses", PLOS ONE, 8 (6), pp. 1-10. 2013.

[27] A. Ezuka, O. Horino, "Classification of rice varieties and Xanthomonas oryzae strains on the basis of their differential interaction", Bull. Tokai-Kinki National Agr. Exp. Sta., 27, 1-19, 1974. 
[28] N. Buensanteai, K. Thumanu, M. Sompong, D. Athinuwat, S. Prathuangwong, "The FTIR spectroscopy investigation of the cellular components of cassava after sensitization with plant growth promoting rhizobacteria, Bacillus subtilis CaSUT007”, African Journal of Microbiology Research, 6, pp. 603-610, 2012.

[29] W. Boonyungyuen, B. Wichitsathian, P. Racho, "Azo dye reduction and biodegradability mechanisms during an anaerobic process", Suranaree Journal of Science and Technology, 20 (1), pp. 1-9, 2013.

[30] K. Thumanu, D. Wongchalee, M. Sompong, P. Phansak, T. Le Thanh, W. Namanusart, K. Vechklang, S. Kaewnum, N. Buensanteai, "Synchrotron-based FTIR microspectroscopy of chili resistance induced by Bacillus subtilis strain D604 against anthracnose disease", Journal of Plant Interaction, 12 (1), pp. 255-263, 2017.

[31] M. Iqbal, A. Saeed, S.I. Zafar, "FTIR spectrophotometry, kinetics and adsorption isotherms modeling, ion exchange, and EDX analysis for understanding the mechanism of $\mathrm{Cd}^{2+}$ and $\mathrm{Pb}^{2+}$ removal by mango peel waste”, Journal of Hazardous Materials, 164, pp. 161-171, 2009.

[32] M. Mularczyk-Oliwa, A. Bombalska, M. Kaliszewski, M. Wlodarski, K. Kopczynski, M. Kwasny, M. Szpakowska, E.A. Trafny, "Comparison of fluorescence spectroscopy and FTIR in differentiation of plant pollens", Spectrochimica Acta Part A: Molecular and Biomolecular Spectroscopy, 97, pp. 246-254, 2012.

[33] R. Lahlali, C. Karunakaran, L. Wang, I. Willick, M. Schmidt, X. Liu, F. Borondics, L. Forseille, P.R. Fobert, K. Tanino, G. Peng, E. Hallin, "Synchrotron based phase contrast X-ray imaging combined with FTIR spectroscopy reveals structural and biomolecular differences in spikelets play a significant role in resistance to Fusarium in wheat", BMC Plant Biology, 15, pp. 24-39, 2015.

[34] C.F.B. Sene, M.C. McCann, R.H. Wilson, R. Grinter, "Fourier transform raman and Fourier transform infrared spectroscopy - An investigation of five higher plant cell walls and their components", Plant Physiology, 106, pp. 1623-1631, 1994.

[35] M.D. Kenneth, C.D. Lawrence, "Use of infrared microspectroscopy in plant growth and development", Applied Spectroscopy Reviews, 40, pp. 301-326, 2005.

[36] K.M. Dokken, L.C. Davis, "Infrared imaging of sunflower and maize root anatomy", Journals of Agricultural and Food Chemistry, 55 (26), pp. 10517-10530, 2007.

[37] P. Yu, J.J. McKinnon, C.R. Christensen, D.A. Christensen, N.S. Marinkovic, L.M. Miller, "Chemical imaging of microstructures of plant tissues within cellular dimension using synchrotron infrared microspectroscopy", Journals of Agricultural and Food Chemistry, 51 (20), pp. 6062-6067, 2003.

[38] S.W. Ellepola, S.M. Choi, C.Y. Ma, "Conformational study of globulin from rice (Oryza sativa) seeds by Fourier-transform infrared spectroscopy", International Journal of Biological Macromolecules, 37, pp. 12-20, 2005. 
[39] J. Wang, J. Zhu, R. Huang, Y.S. Yang, "Investigation of cell wall composition related to stem lodging resistance in wheat (Triticum aestivum L.) by FTIR spectroscopy", Plant Signaling \& Behavior, 7 (7), pp. 856-863, 2012.

[40] A. Alonso-Simon, E.A. Encina, P. Garcia-Angulo, J.M. Alvarez, J.L. Acebes, "FTIR spectroscopy monitoring of cell wall modifications during the habituation of bean (Phaseolus vulgaris L.) callus cultures to dichlobenin”, Plant Science, 167, pp. 1273-1281, 2004.

[41] M. Kacurakova, P. Capek, V. Sasinkova, N. Wellner, A. Ebringerova, "FT-IR study of plant cell wall model compounds: pectic polysaccharides and hemicelluloses", Carbohydrate Polymers, 43, pp. 195-203, 2000.

[42] A. Chiş, F. Fetea, H. Matei, C. Socaciu, "Evaluation of hydrolytic activity of different pectinases on sugar beet (Beta vulgaris) substrate using FT-MIR spectroscopy", Notulae Botanicae Horti Agrobotanici Cluj-Napoca, 39 (2), pp. 99-104, 2011.

[43] E. De Neergaard, Methods in botanical histopathology, Danish Government Institute of Seed Pathology for Developing Countries, Danmark, 216p, 1997.

[44] K. Kazan, P.M. Schenk, "Genomics in induced resistance", in Induced resistance for plant defence - A sustainable approach to crop protection, D. Walter, A. Newton, G. Lyon (Eds.), Blackwell Publishing Ltd., Oxford (UK), pp. 31-64, 2007.

[45] J.L. Zhou, C.H. Lee, R.Q. Zhong, Z.H. Ye, "MYB58 and MYB63 are transcriptional activators of the lignin biosynthetic pathway during secondary cell wall formation in Arabidopsis", Plant Cell, 21, pp. 248-266, 2009.

[46] J. Stork, D. Harris, J. Griffiths, B. Williams, F. Beisson, Y. Li-Beisson, V. Mendu, G. Haughn, S. Debolt, "Cellulose Synthase 9 serves a nonredundant role in secondary cell wall synthesis in Arabidopsis epidermal testa cells", Plant Physiology, 153, pp. 580-589, 2010. 